\title{
Algal Cell Factories: Approaches, Applications, and Potentials
}

\author{
Weiqi Fu ${ }^{1}$, Amphun Chaiboonchoe ${ }^{1}$, Basel Khraiwesh ${ }^{2}$, David R. Nelson ${ }^{2}$, Dina Al-Khairy ${ }^{1}$, \\ Alexandra Mystikou ${ }^{1}$, Amnah Alzahmi ${ }^{2}$ and Kourosh Salehi-Ashtiani 1,2,* \\ 1 Division of Science and Math, New York University Abu Dhabi, P.O. Box 129188 Saadiyat Island, Abu Dhabi, \\ UAE, wf21@nyu.edu (W.F.); ac4793@nyu.edu (A.C.); dak9@nyu.edu (D.A.-K.); amystikou@gmail.com (A.M.) \\ 2 Center for Genomics and Systems Biology (CGSB), New York University Abu Dhabi, P.O. Box 129188 \\ Saadiyat Island, Abu Dhabi, UAE, bhk1@nyu.edu (B.K.); drn2@nyu.edu (D.R.N.); \\ amnah.alzahmi@nyu.edu (A.A.) \\ * Correspondence: ksa3@nyu.edu; Tel.: +971-2-628-4546
}

Academic Editor: Georg Pohnert

Received: 31 October 2016; Accepted: 5 December 2016; Published: 13 December 2016

\begin{abstract}
With the advent of modern biotechnology, microorganisms from diverse lineages have been used to produce bio-based feedstocks and bioactive compounds. Many of these compounds are currently commodities of interest, in a variety of markets and their utility warrants investigation into improving their production through strain development. In this review, we address the issue of strain improvement in a group of organisms with strong potential to be productive "cell factories": the photosynthetic microalgae. Microalgae are a diverse group of phytoplankton, involving polyphyletic lineage such as green algae and diatoms that are commonly used in the industry. The photosynthetic microalgae have been under intense investigation recently for their ability to produce commercial compounds using only light, $\mathrm{CO}_{2}$, and basic nutrients. However, their strain improvement is still a relatively recent area of work that is under development. Importantly, it is only through appropriate engineering methods that we may see the full biotechnological potential of microalgae come to fruition. Thus, in this review, we address past and present endeavors towards the aim of creating productive algal cell factories and describe possible advantageous future directions for the field.
\end{abstract}

Keywords: algae; bioactive compound; cell factory; genetic engineering; mutagenesis; systems biology

\section{Introduction}

Microalgae have drawn great attention as a promising source for sustainable production of fatty acids, carotenoids, vitamins, and other compounds of interest [1]. Altogether, secondary metabolites from microalgae have great potential for industrial development as they include bioactive compounds such as antioxidant, antiviral, antibacterial, antifungal, anti-inflammatory, antitumor, and antimalarial effectors [2]. For example, nutritional lipids including essential fatty acids such as docosahexaenoic acid (DHA) have been commercially produced from microalgae [3]. However, natural products in microalgae remain largely unexplored compared to those in land plants [2], even though cultivation of microalgae offers many advantages over those of terrestrial plants, e.g., the rapid growth rates, and lack of competition for resources used for food crops, including the use of fresh water and arable lands.

The important fact that microalgae have been granted the GRAS (Generally recognized as safe) status opens the path wide for the use of microalgae as an attractive cell factory. The U.S. FDA (Food Drug Administration) issues a GRAS certificate and grants this "safe to consume" status depending on studies and scientific literature and evidence that the material in question is not harmful under predetermined conditions of use. This GRAS classification is critical as it cut costs of downstream 
purification of compounds or proteins purified as this status eliminates the need for further purification steps. As such, many algae species are considered GRAS [4]. For instance, Spirulina has been recognized as GRAS by the FDA with no risk for human health since 1981 [5]. Species of green microalgae such as Chlorella and Dunaliella, which are a rich source of vitamins, lipids, and other bioactive compounds, are also considered GRAS by FDA [5].

The microalgae have proven to be of considerable interest as a source of bioactive compounds and applied research in this field is growing dramatically (Figure 1). Although genetically unmodified microalgae may be exploited for the production of particular metabolites that they can accumulate, it is expected that strain development is required to make industrial production feasible. Therefore, there is a need to develop new production strains with features such as fast growth, high tolerance to lights and heat, etc. To date, some approaches have been developed to increase algal productivity for value-added bioproducts. Mutagenesis, adaptive laboratory evolution (or ALE), and genetic engineering have been established as strategies for developing algal cell factories. Furthermore, systems biology and synthetic biology perspectives and approaches are emerging in the production of bioactive compounds, such as carotenoids and vitamins, in algae [6,7]. In addition, using in silico metabolic models to complement and contextualize genetic and metabolic data will provide researchers more options for the strain improvement of target products [8-11]. However, the progress in the field is not well documented, and significant achievements on developing algal cell factories are yet to be recognized. In this article, we review, and comment on recent progress on metabolic engineering and strain improvement in microalgae research with examples using mutagenesis, adaptive evolution, genetic engineering, and systems biology approaches (Figure 2).

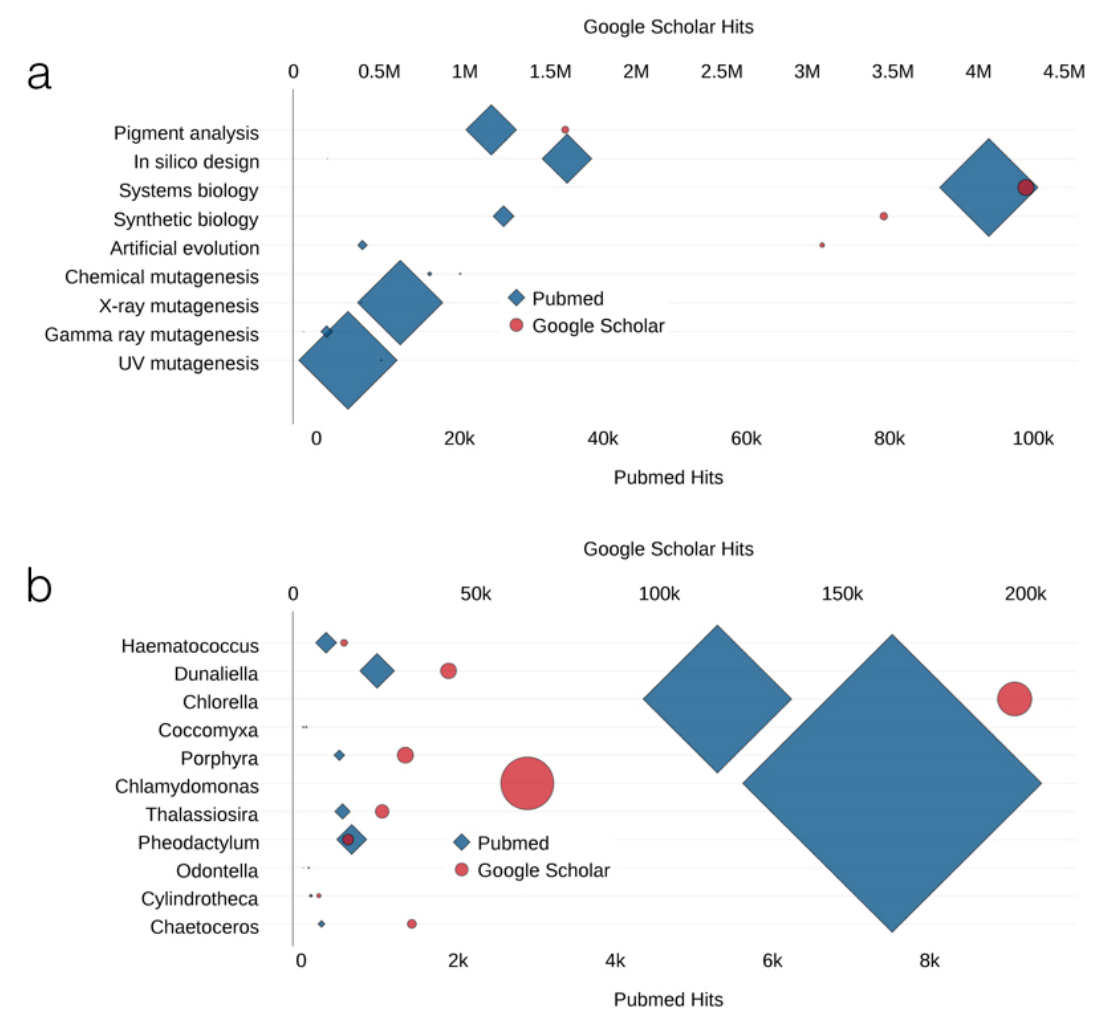

Figure 1. Trends in algal research: (a) Results of queries in PubMed and Google Scholar search engines with topic terms are shown on $x$-axes (bottom, PubMed; top, Google Scholar); the number of hits for topic term "AND algae" are indicated by size. (b) The number of hits for algal species are shown on the $x$-axes (bottom, PubMed; top, Google Scholar); the number of hits for algal species AND (synthetic OR systems OR in silico OR artificial evolution OR mutagenesis OR pigment) are indicated by size. 


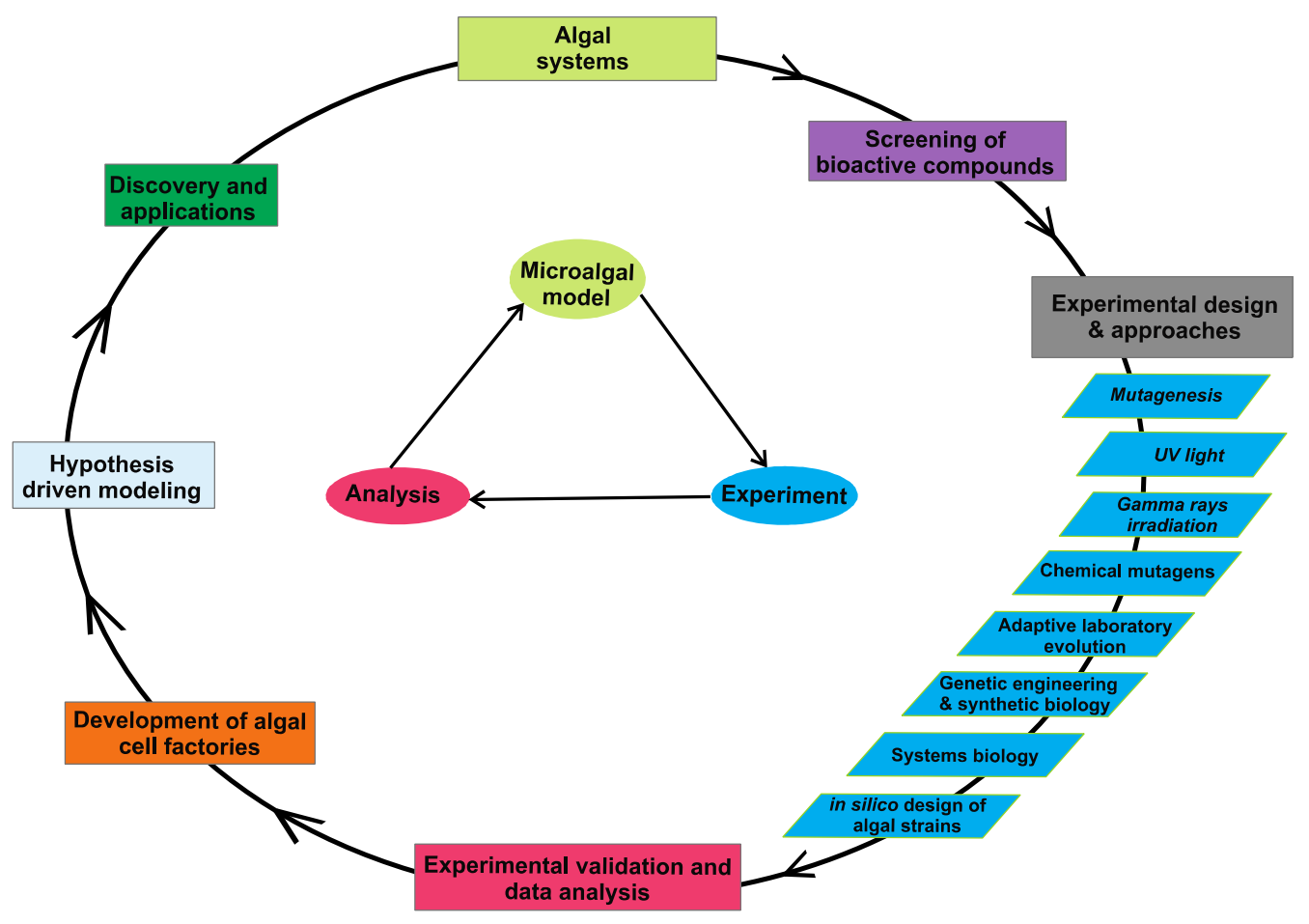

Figure 2. A conceptual representation of an integrative strain-engineering approach. Various experimental and -omics datasets are integrated with metabolic modeling for the development of algal cell factories.

\section{Approaches for Developing Algal Cell Factories}

Microalgae are photosynthetic eukaryotic organisms, which may be drawn up as model organisms for the sustainable production of fine chemicals such as nutritional supplements, carotenoids and polyunsaturated fatty acids (PUFAs) [12]. There are many parameters that can be used to increase pigment and lipid production in microalgae, for example, nutrient starvation, light stress and other stress conditions. In this section, current and different types of physical and chemical mutagens to develop algal cell factories will be reviewed with specific examples. Further, emerging technologies in the field for strain development will be discussed.

\subsection{Mutagenesis}

Mutagenesis in laboratories is a process in which a physical or chemical mutagen is used to induce a higher frequency of mutation than the natural rate of a particular organism. Then, stable mutants with improved traits may be screened and selected with changed and inheritable genetic information thereafter for the development of desired new variants [13]. Many physical mutagens including UV light and gamma and X-rays, as well as chemical mutagens, have been successfully applied on microalgae for improving strain performance [13].

\subsubsection{UV Light}

Ultraviolet [14] light induces specific mutations that are usually caused by the induced formation of pyrimidine dimers on the same strand of DNA [15]. After exposure to either UVA or UVB, mutation is observed occurring preferentially at methyl-CpG sites [15]. UV mutagenesis is still a useful method in microalgae mutagenesis since it can be employed without clear genetic information from microalgae species. Compared with chemical mutagenesis methods, UV mutagenesis can be controlled more flexibly to avoid secondary contamination. Previous studies have shown that UV mutagen on organisms achieved Dunaliella bardawil mutant strains that are rich in $\beta$-carotene. UV mutagenesis also 
increased the eicosapentaenoic acid [16] accumulation in the diatom Phaeodactylum tricornutum [16] and EPA and docosahexaenoic acid production [17] in Pavlova lutheri [18], respectively. UV mutagenesis has also been shown as an efficient method to improve both the biomass and the lipid content in Chlorella strains [18].

We recently developed and demonstrated the application of UV mutagenesis integrated with fluorescence-activated cell sorting (FACS) for selection, and confocal Raman microscopy for lipid analysis in Chlamydomonas as a model for generating lipid-accumulating microalgae $[19,20]$. Raman microscopy enabled quantitative determination of the unsaturation levels and chain lengths of microalgal lipids, which are vital parameters in selection and engineering of microalgae for optimal production of biofuels. The obtained results demonstrated the presence of stable clonal differences on saturation status of expressed lipids $[19,20]$.

\subsubsection{Gamma Rays Irradiation}

Gamma rays are very short wavelengths obtained by the disintegration of the radioisotopes ${ }^{60} \mathrm{Co}$, ${ }^{123}$ I or ${ }^{137}$ Cs. Most gamma sources are suitable for seed irradiation, as long as the size of irradiation space is sufficient and the dose rate allows reasonable irradiation times [13]. For instance, breeding via gamma irradiation has been used to develop a high lipid-producing Scenedesmus dimorphic mutant [21].

\subsubsection{Chemical Mutagens}

Chemical mutagens induced mutagenesis may be particularly biased in some cases, as they may increase the mutation levels, particularly in some genomic regions with high GC-content. It is expected that some mutagenesis experiments may not result in desired phenotypes due to limited mutant pools. Therefore, it is important to understand the biases before selection of a chemical mutagen for mutagenesis experiments [22].

$N^{\prime}$-nitro- $N$-nitrosoguanidine (NTG) is a common chemical mutagen that has been widely used in Escherichia coli and other bacteria such as Corynebacterium glutamicum [22]. NTG has also been successfully used to generate mutants with enhanced carotenoid accumulation and increased astaxanthin content in the green alga Haematococcus pluvialis [23]. Ethyl methanesulfonate (EMS) is another popular chemical mutagen that has been proven to be effective and efficient in mutagenesis [13]. Successful mutagenesis has been performed using EMS to create algal mutants with increased lipid accumulation. For example, Chlamydomonas reinhardtii was randomly mutagenized by EMS for enhanced lipid production [24].

\subsection{Adaptive Laboratory Evolution}

Adaptive laboratory evolution (ALE) has been widely utilized for developing novel biological and phenotypic functions and also for strain improvement in synthetic biology for prokaryotic microorganisms that have mostly consisted of bacteria strains [25-27]. ALE experiments under well-controlled laboratory conditions followed by genome re-sequencing allowed us to study the genetic basis underlying adaptation to environmental stress. With the aid of cost-effective genome re-sequencing, it becomes feasible to identify the mutations occurred under selection pressure during ALE.

ALE approaches have also been applied to adaptively evolve eukaryotic microalgae to grow under controlled light conditions for increased carotenoid accumulation [28,29]. Numerous studies have been reported on the adaptation of cyanobacteria to abiotic stressors such as long-term thermal tolerance, butanol treatment, acid stress and high light stress [30-32]. However, these studies have mainly focused on identification of genetic modifications leading to the new phenotypic strains and rarely put any efforts on developing strains for improved production of bioactive compounds in cyanobacteria. 
In green microalgae, the nuclear, chloroplast and mitochondrial genomes of the model species C. reinhardtii have been fully sequenced and annotated. Adaptive evolution studies on C. reinhardtii strains were dedicated to lipid metabolism for high lipid accumulation or biofuel production [33-35]. Using a long time iterative light stress or ALE yielded $D$. salina strains with increased accumulation of carotenoids including $\beta$-carotene and lutein [28]. It has also been reported that ALE improved the high $\mathrm{CO}_{2}$ tolerance of Chlorella sp. and achieved increased accumulation of chlorophylls and carotenoids [36].

Diatoms have a different evolutionary history compared to green microalgae. They are thought to have evolved from an ancient secondary endosymbiosis between heterotrophic and autotrophic eukaryotes [37,38]. Diatoms containing different pigments different from green algae and higher plants in the light-harvesting complex are capable of generating significant amounts of specific compounds in response to fluctuations in environments, particularly about changes in illumination. Blue light is believed to be essential for high light acclimation in P. tricornutum [39], but the molecular basis of responses to light in marine diatoms is still largely unknown [16]. It is thought that high light acclimation in P. tricornutum is triggered by the redox state of the plastoquinone pool, similar to green algae and land plants [40]. A recent study showed that P. tricornutum strains developed by ALE achieved higher biomass production and enhanced fucoxanthin accumulation under combined red and blue light conditions, but the genetic mutations which may be potentially responsible for the altered phenotypes have not been deciphered yet [29].

In addition to the typical groups of microalgae, other marine species may be able to respond to environmental changes through adaptive evolution. For example, the coccolithophore Emiliania huxleyi, one marine alga that generates calcite scales biogenically and can produce alkenones, a compound associated with resistance to environmental stress, evolved in response to ocean acidification in 500 asexual generations and exhibited higher growth rates in adapted cultures, compared with the non-adapted culture [41].

In short, to conduct ALE on microalgae for strain optimization, one may need to select and determine useful selection parameters. These parameters involve growth-rate selection pressures such as light stress and nutrient depletion, solvents treatment such as using butanol as well as antibiotics, depending on the metabolic pathways that one may target. Intensive genome sequencing may help to reveal the genetic basis for adaptation of microalgae to environmental stress. For a comprehensive and in-depth understanding and application of ALE, genetic engineering and synthetic biology approaches may be developed to reintroduce point or combined mutations into wild-type starting strains for determining specific phenotypic consequences.

\subsection{Genetic Engineering}

This section focuses on the progress and emerging technology of genetic engineering in eukaryotic microalgae. Eukaryotic microalgae possess all the advantages of photosynthetically driven systems but lack many of the disadvantages of plant-based expression systems, i.e., they have higher growth rates, are easy to grow and do not compete for lands with crops in agriculture [42]. The first and best-studied eukaryotic microalga is the soil and freshwater species $C$. reinhardtii, which its nuclear genetic manipulation system has been well established [43,44]. The enzyme $\beta$-carotene ketolase from $H$. pluvialis has been expressed in $C$. reinhardtii to synthesize the carotenoids ketolutein and adonixanthin [45]. In addition, the nuclear transformation of $C$. reinhardtii using genes isolated from Chlorella zofingiensis was developed, and engineering C. reinhardtii with a foreign phytoene synthase led to an increase of the carotenoids violaxanthin and lutein which were 2.0- and 2.2-fold higher than in untransformed cells $[46,47]$. 
Molecular biology tools for gene manipulation in diatoms have also been developed [42,48]. Microprojectile bombardment and electroporation have been applied successfully to introduce foreign DNA into Phaeodactylum cells for which the full genome sequence is available [49]. A shuttle vector (pPha-NR) with an inducible nitrate reductase promoter system (GenBank: JN180663) has been constructed for controllable expression of foreign genes [42]. Recently, the diatom P. tricornutum was engineered to accumulate the high value omega- 3 polyunsaturated fatty acid docosahexaenoic acid [17] by incorporating the $\Delta 5$-elongase and acyl-CoA-dependent $\Delta 6$-desaturase genes from the picoalga Ostreococcus tauri [50].

Another well-established DNA delivery technique is transformation by Agrobacterium tumefaciens, a soil pathogenic bacteria that causes crown gall disease [51]. In recent years, this method has been successfully applied in algae [52]. Stable nuclear genetic transformation of $C$. reinhardtii mediated by agrobacterium has been reported [51]. Agrobacterium-mediated transformation has shown success in oil-bearing marine algae Parachlorella Kesslerri [52] and Schizochytrium [53], of which the latter is used for commercial production of oil rich in DHA.

Using reverse genetics approaches such as homologous recombination, genetic engineering strategies using microalgae for enhanced production of value-added compounds can be developed. More precise genome editing tools such as zinc-finger nuclease (ZFN), transcription activator-like effectors (TALEs) and clustered regularly interspaced short palindromic repeats (CRISPR) have also been developed for gene activation, deletion and replacement in organisms as emerging technology. However, only a limited number of studies have been reported on engineering microalgae through these advanced genome editing tools, for example, ZFN-mediated gene editing in the green microalga C. reinhardtii and the use of TALEs in the marine diatom P. tricornutum [54]. It was reported that using CRISPR/Cas9 system for targeted gene modification in C. reinhardtii succeeded with an expression of Cas9 and single guide RNA (sgRNA) genes while the study suggested the failure to recover transformants of $C$. reinhardtii was caused by the toxicity of Cas9 produced constitutively following gene editing [55]. More recently, it was shown that delivering Cas9 ribonucleoproteins (RNPs) comprising the Cas9 protein and sgRNAs in contrast to vector-driven expression of Cas9 can improve the targeting efficiency of CRISPR/Cas9 in Chlamydomonas [56]. Another study reported the development of a CRISPR/Cas9 based system to create stable gene knockouts in the marine diatom P. tricornutum [57]. It appears much effort is needed to develop the genome editing technology that works effectively in microalgae.

Synthetic biology is an emerging research technology that enables us to redesign and construct biological devices and systems for producing target compounds [58]. However, synthetic biology is still a young field undergoing rapid development. Currently, due to the lack of highly efficient and effective tools for modification of target genes in the nuclear genome in microalgae, more investigations are required to fully exploit the potential of microalgae through various strategies [58,59]. Nevertheless, synthetic biology is very likely to play a major role in developing microalgae for bioactive compounds in the coming years. Recently, one of the diatom P. tricornutum chromosomes was successfully generated synthetically and maintained in yeast. The applications of these techniques will likely offer opportunities to reverse-engineer, then redesign a variety of algal species at genome-scales towards industrial applications [58].

\subsection{Systems Biology and In Silico Design of Algal Strains}

Systems biology is based on the large-scale high-throughput quantitative omics technologies including genomics, proteomics, metabolomics and transcriptomics and bioinformatics tools lead to a more comprehensive understanding of how the metabolisms varied in different environmental conditions, functional diversity and biosynthetic capacity [60]. Systems biology has become a valuable approach for understanding cellular metabolism, identify potential enzymes and pathways for metabolic engineering targets and improve microalgal strains to increase their productivity especially in the production of complex natural products $[61,62]$. 
Using next-generation sequence data, genome-scale metabolic model (GSM) for different organisms have been reconstructed and are being updated as new toolboxes are being developed [63]. The in silico genome-scale models have also enabled development of metabolic engineering strategies to optimize algal strains by improving and maximizing the yield of bioactive compounds of interest [64]. Pathway Tools [65] is one of the available software that can be used to manage, analyze, simulate and visualize the pathways, as well as for prediction of metabolic routes of the compound of interest. Constraint-based reconstruction and analysis (COBRA) [63] methods have become well known and widely used tools for metabolic and genetic engineering. GSM using COBRA to compute optimal flux distribution through the flux balance analysis (FBA) and strain optimization tools such as OptORF [66], EDGE [67] and Optknock [68] to predict gene overexpression and/or gene deletion, has been applied in identifying good strain candidates and generating hypothesis-driven strain engineering to achieve improved yield of target products. To date, some GSM have been reconstructed on algae but not yet fully utilized in bioactive compound production. Among microalgae, C. reinhardtii's GSM is a widely used model, which has been reported, refined and updated some times $[64,69,70]$. Furthermore, the GSM for green picoalga Ostreococcus including two species O. lucimarinus and O. tauri were constructed [71]. In addition, GSM model of P. tricornutum has been developed [72] and recently updated to "iLB1027_lipid" model [73]; the model was utilized to understand the species response to light intensity [74].

Chlorella spp., a unicellular green microalga that is widely distributed in freshwater has been recognized as a promising candidate for biomass, biofuel, and value-added chemical production. C. protothecoides sequence available in 2014 [75] and primary metabolic model reconstruction is currently available (272 metabolic reactions, 270 enzymes, and 461 encoding genes and 190 metabolites) [76]. C. variabilis, $i$ AJ526, was reconstructed with 526 genes, 1445 reactions and 1236 metabolites based on C. variabilis NC64A strain under three light sources [77]. The model for C. vulgaris UTEX 395, iCZ843, is the most comprehensive reconstruction (843 genes, 2294 reactions, and 1770 metabolites) [78] of the Chlorella models. Importantly, this reconstruction makes use of the Biolog phenotype microarray platform $[70,79]$ to validate some reactions and pathways.

Arthrospira is a genus of cyanobacteria that has seen a significant advance in its application in various fields including food, fuel and pharmaceutical industries. The iAK692 model is the first comprehensive GSM for Spirulina (Arthrospira platensis) that was derived from partial genome sequences through a semi-automated process based on the Pathway Tools software. The model contains 692 open reading frames (ORFs). This research provides an example of how the models can improve the industrial use of this strain [17]. Cyanobacteria are also a group of organisms with potential for development of cell factories. Their comprehensive genome-scale metabolic models have been published $[80,81]$ and simulated to explore how carbon and energy are distributed. The iSyf715 model is a GSM model for Synechococcus elongatus PCC7942 [82], and iSyn669 [83] and iJN678 [84] are GSM for Synechocystis sp. PCC 6803. A novel gap-filling tool, MetabolIc Reconstruction via functionAl GEnomics (MIRAGE), has been applied to Synechocystis sp. PCC 6803 with a computational metabolic engineering tool called Optknock [68] to enhance astaxanthin production [85]. Recent web-based tools for system biology analysis for cyanobacteria can be found in recent reviews [86] and their application to the synthesis of industrial products was reported $[87,88]$.

GSM of other organisms has been used to clarify DHA [17] biosynthesis mechanism and improve DHA production using iCY1170_DHA model of Schizochytrium limacinum SR21 [89]. A Gram-positive Bacillus subtilis iBsu1147 model also showed how the model could help to increase the following products: riboflavin, cellulase Egl-237, $(R, R)-2,3$-butanediol, and isobutanol [90]. GSM may also help to study the adaptation process since the optimal growth solutions can be computed from GSM and then utilized to interpret changes observed by comparing transcriptomic patterns from the wild-type and ALE strains. 
Altogether, microalgae are promising sources of bioactive compounds, but there are still challenges to be addressed. With complete genome sequences of microalgae, available genetic manipulation tools, genome-scale metabolic models, omics data analyses can lead to a better understanding of biosynthetic pathways and optimization of the strains for enhanced production of target products.

\section{Cell Factory Potentials in Macroalgae and Lower Plants}

In addition to microalgae, macroalgae and mosses are briefly discussed as potential photosynthetic cell factories in this section for their applications in biotechnology. Macroalgae constitute a renewable resource used by the food industry, as feed for animals, to produce phycocolloids, as cosmetic ingredients and for pharmaceutical applications. The moss Physcomitrella patens, which is a bryophyte, occupies a key evolutionary position bridging the gap between green algae and higher plants [91]. Because the protonema stage of the species grows quickly and simultaneously, it can be cultivated in a bioreactor as a genetically stable cell suspension. Physcomitrella can be easily manipulated using standard molecular biology methods and is haploid in a vegetative state, making it a highly suitable system for engineering strains towards industrial applications $[92,93]$.

\subsection{Macroalgal Species}

A promising group of phototrophic organisms for biotechnology applications are the macroalgae (brown, Phaeophyta; red, Rhodophyta; and green, Chlorophyta) as they constitute diverse sources of natural products. Trosset and Carbonell [94] suggest and discuss the application of systems biology to red macroalgal species that have been identified as rich sources of diverse and novel bioactive compounds for drug development. Many of these molecules have high commercial value for nutritional supplements, specialty pigments, industrial polysaccharides and aquaculture [95]. Others produce bioactive compounds including ones with antibacterial, anti-tumor, antiviral and antifungal activities [96]. For example, many brown (e.g., Laminaria saccharina) and red (e.g., Agardhiella subulala) marine macroalgae produce bioactive compounds such as eicosanoids, which have substantial bioactivity against inflammation, asthma, heart diseases and cancer. A few other macroalgal species, such as members of Ochtodes, Plocamium, and Portieria, produce halogenated monoterpenes that may provide anti-tumor activities [97]. These macroalgal species are potential candidates for cell factory development. Thus far, stable and transient genetic transformations have been developed for seven macroalgal species to change or enhance their bioactivity. These species are: Pyropia yezoensis (Table 1), Porphyra miniata, Kappaphycus alvarezii and Gracilaria changii from the red algal phylum; Saccharina japonica (Table 1) and Undaria pinnatifida from the brown phylum; and the green alga Ulva lactuca [98]. The species above are prime candidates for future cell factory developments due to the availability of their genetic information; this is an advantage that can offer a better understanding for genetically engineering them. While the genomic knowledge about macroalgae is limited, the complete genomes of Ectocarpus siliculosus, Pyropia yezoensis, Gracilariopsis lemaneiformis, Chondrus crispus and Saccharina japonica have been sequenced; these can serve as model species to established genetic engineering in macroalgal species [99].

According to the Food and Agriculture Organization of the United Nations [100], algae constitute a large fraction of the global source for food production, pharmaceuticals, cosmetics and fertilizers, and are processed to extract thickening agents or used as an additive to animal feed with high commercial value. Algal farming is practiced for 37 different species in about 50 countries with a total estimated annual value of US\$6.4 billion. Macroalgae such as Pyropia spp. have high nutritional value and are being used extensively for consumption especially in Asian countries. Farming is producing up to 27 million tons of macroalgae for commercial use, and it has been expanded by eight percent per year over the past decade. 


\subsection{The Moss P. patens}

Over the past 20 years, the moss P. patens has been developed as a model species in basic research and biotechnology $[101,102]$ and can be a good candidate for the production of natural products, which are difficult of access. Several human proteins are being produced in this system as potential biopharmaceuticals [102]. Among the products are tumor-directed monoclonal antibodies with enhanced antibody-dependent cytotoxicity (ADCC), vascular endothelial growth factor (VEGF), complement factor $\mathrm{H}(\mathrm{FH})$, keratinocyte growth factor (FGF7/KGF), epidermal growth factor (EGF), hepatocyte growth factor (HGF), asialo-erythropoietin (asialo-EPO, AEPO), alpha-galactosidase (aGal) and beta glucocerebrosidase (GBA) [102]. The first moss-made pharmaceutical, aGal to treat Morbus Fabry, is in clinical trials [102]. Subsequently, a mutant was engineered to further "humanize" the moss glycosylation pattern by the expression of a human beta-1,4-galactosyltransferase gene. This gene was integrated into the Physcomitrella patens genome by "knockin" into the xylosyltransferase or fucosyltransferase locus [103]. To avoid unwanted O-glycosylation of human proteins produced in moss, a gene responsible for prolylhydroxylation was identified and deleted from the genome [104]. The first human protein produced in the moss system was the vascular endothelial growth factor (VEGF) [105], which has a central function in angiogenesis and cancer [106]. Several human growth factors (FGF7/KGF, EGF, and HGF) that are used in mammalian cell culture have been produced in the moss system [107]. We note that FGF7/KGF (keratinocyte growth factor) is the first commercially available moss-made human protein, intended for in vitro use. Based on these experiences, Moss has been suggested as a potential production host for vaccines [108], vaccine-producing moss may be directly administered as an oral vaccine. The first moss-made candidate vaccine is a chimeric Env-derived HIV multi-epitope protein that is immunogenic in mice [109]. An important issue in good manufacturing practice (GMP) is the molecular characterization of the producing cell factories. Once characterized and approved, subsequent production has to rely on identical clones that have to be stored in master cell banks. This can easily be achieved for clonal moss tissues, as they can be stored in liquid nitrogen and survive this cryopreservation to $100 \%$ even after many years [110]. 
Table 1. Phototrophic species with available genome sequences or ongoing genome sequencing projects and additional information (where exist) about their environment, bioactive compounds, and properties/extracts. Data presented are available in the NCBI genome database (http://www.ncbi.nlm.nih.gov/) and the AlgaeBase website (http:/ /www.algaebase.org/) [111].

\begin{tabular}{|c|c|c|c|c|c|c|}
\hline Species & Group & Environment & Bioactive Compounds & Properties & Genetic Tools & Ref. $^{1}$ \\
\hline Bigelowiella natans & Cercozoa & marine & & & $\begin{array}{l}\text { Genome; transcriptome under diurnal cycle; Viral } \\
\text { elements known }\end{array}$ & [112-114] \\
\hline Chlorella sp. & Chlorophyta & freshwater & Lipids, human growth hormone & Human nutrition, biofuels, medicines & Genes for active enzymes cloned; in silico models & [115-119] \\
\hline Coccomyxa subellipsoidea & Chlorophyta & freshwater & Flounder growth hormone & $\begin{array}{l}\text { Flounder fry exposed to Chlorella-expressed } \\
\text { fGH for } 30 \text { days exhibited a } 25 \% \text { increase in } \\
\text { both total length and width }\end{array}$ & Trans gene expression & {$[115,120]$} \\
\hline Ostreococcus lucimarimus & Chlorophyta & marine & asymmetric carotenoids & Antioxidant molecules, human nutrition & Trans gene expression & {$[121,122]$} \\
\hline Micromonas pusilla & Chlorophyta & marine & & & $\begin{array}{l}\text { Trans gene expression, } \\
\text { cDNA libraries }\end{array}$ & [123] \\
\hline Volvox carterif. nagariensis & Chlorophyta & freshwater & & & $\begin{array}{l}\text { Trans gene expression, } \\
\text { cDNA libraries }\end{array}$ & [124] \\
\hline Chlamydomonas reinhardtii & Chlorophyta & freshwater & & Human nutrition, biofuels & $\begin{array}{l}\text { Trans gene expression, } \\
\text { cDNA libraries }\end{array}$ & {$[125,126]$} \\
\hline Emiliania huxleyi & Haptophyta & marine & Calcium carbonate, dimethyl sulfoxide & Human nutrition, weather influence & cDNA libraries & {$[127,128]$} \\
\hline Guillardia theta & Cryptophyta & marine & & & Functional genes cloned for trans-expression in E. coli & [129] \\
\hline Nannochloropsis gaditana & Chrysophyta & marine & lipids & Human nutrition, biofuels & Trans gene expression & {$[130,131]$} \\
\hline Ectocarpus siliculosus & Phaeophyta & marine & & & Trans gene expression & [132] \\
\hline Saccharina japonica & Phaeophyta & marine & $\begin{array}{l}\text { porphyrin derivatives (pheophorbide } \\
\text { a, pheophytin a) }\end{array}$ & anti-inflammatory activity & SNP linkage map & {$[2,133]$} \\
\hline Thalassiosira oceanica & Phaeophyta & marine & & & cDNA libraries, RNAi, cloning of functional genes & [134] \\
\hline Thalassiosira pseudonana & Phaeophyta & marine & lipids & Human nutrition & & [125] \\
\hline Phaeodactylum tricornutum & Phaeophyta & marine & lipids & Human nutrition, biofuels & cDNA libraries, Trans gene expression, in silico models & {$[125,135,136]$} \\
\hline Cyanidioschyzon merolae & Rhodophyta & freshwater & lipids & Human nutrition, biofuels & Trans gene expression & {$[137,138]$} \\
\hline Pyropia yezoensis & Rhodophyta & marine & $\begin{array}{c}\text { carotenoids, vitamin B12, PGP } \\
\text { glycoprotein, Usujilene- -kind of } \\
\text { mycosporine-glycine like amino acid }\end{array}$ & $\begin{array}{c}\text { food applications (nori in suschi), } \\
\text { anti-inflammatory activity, } \\
\text { antioxidative activity }\end{array}$ & Functional genes cloned & {$[2,139-142]$} \\
\hline $\begin{array}{l}\text { Gracilariopsis } \\
\text { lemaneiformis }\end{array}$ & Rhodophyta & marine & $\begin{array}{l}\text { fatty acid (12S-hydroxyeicopentaenoic } \\
\text { acid-12S-HEPE) }\end{array}$ & Human nutrition & Protoplast fusion & [143] \\
\hline Chondrus crispus & Rhodophyta & marine & carrageenan & Food applications & Established qPCR references & [96] \\
\hline Synechococcus elongatus & Cyanophyta & freshwater & exopolymers & Carbon cycling, materials applications & $\begin{array}{l}\text { Trans gene expression, Tn5 mutagenesis, fusion } \\
\text { PCR, CRISPR }\end{array}$ & [144] \\
\hline Anabaena variabilis & Cyanophyta & freshwater & $\beta$-Carotene hydroxylase & & Trans gene expression & [145-147] \\
\hline Anabaena cylindric & Cyanophyta & freshwater & scytophycin & antifungal activity & & {$[148,149]$} \\
\hline
\end{tabular}

${ }^{1}$ References either for bioactive compounds or genetic tools from listed species in that row only. 


\section{Concluding Remarks and Perspectives}

Microalgae have been recognized for their potential applications in industry. It is feasible to use microalgae in manufacturing facilities, converting $\mathrm{CO}_{2}$, water and sunlight to bioactive compounds such as carotenoids and fatty acids. However, from a critical point of view for sustainability, certain hurdles for using this particular production system needs to be addressed, for instance, the capacity for different product lines and the low photosynthetic efficiency and productivity. In tackling many of these challenges, systems biology and synthetic biology approaches may have great potential in developing photosynthetic cell factories effectively. The advancement of genetic engineering tools and the availability of algal genome data allow new algal species to be engineered and hence used as powerful cell factories for producing novel products of pharmaceutical and industrial value. Furthermore, the evolving omics technologies may lead to data-driven design and strain development on microalgae with reasonable efficiency. We anticipate that the rapid development of these innovative technologies will offer further opportunities for producing active pharmaceutical ingredients as well as discovering new therapeutic compounds in microalgae.

To summarize, microalgae have been regarded as promising and powerful cell factories for their significant role in global sustainability initiatives such as sustainable industry, sustainable agriculture, and ecological economics. Large-scale production using microalgae requires shorter periods of cultivation time in comparison with terrestrial plants, with many microalgae having doubling times of less than $24 \mathrm{~h}$ while land crops are seasonal. In addition, many algae have been granted the GRAS status, which makes the use of microalgae as cell factories for industrial and pharmaceutical purposes very attractive [150]. For engineering these microalgae, using forward genetic approaches may not affect their GRAS status. Even using genome-editing technology such as CRISPR/Cas9 system may fall outside the GMO legislation as long as no foreign DNA has been introduced into their genomes [151]. However, the GRAS status could be invalid if substances are expected to become components of the algal products as a result of genetic modification and the composition of such products has been changed [152]. Moreover, microalgae are still being considered as an alternative solution for the food versus fuel when used to produce biofuels instead of plant-derived biofuels that use fertile land [153]. Furthermore, microalgae can be grown in enclosed photobioreactors, which grants full containment of the genetically modified strains. In contrast, a significant level of concern remains on the use of transgenic plants because open land is used for their cultivation. These advantages and the high nutritional and pharmaceutical values that microalgae have, along with the broad range of antimicrobial bioactive compounds that algae contain, makes algae the best candidate for development of cell factories.

Acknowledgments: Financial support for this work was provided by New York University Abu Dhabi (NYUAD) Institute grant G1205-1205i, NYUAD Faculty Research Funds AD060, and NYUAD Research Enhancement Fund RE500.

Conflicts of Interest: The authors declare no conflict interest.

\section{References}

1. Raposo, M.F.D.; de Morais, R.M.S.C.; de Morais, A.M.M.B. Health applications of bioactive compounds from marine microalgae. Life Sci 2013, 93, 479-486. [CrossRef] [PubMed]

2. Michalak, I.; Chojnacka, K. Algae as production systems of bioactive compounds. Eng. Life Sci. 2015, 15, 160-176. [CrossRef]

3. DSM in Food, Baverages and Dietary Supplements. Nutritional Lipids. Available online: http: //www.dsm.com/markets/foodandbeverages/en_US/products/nutritional-lipids.html (accessed on 25 November 2016).

4. Rosenberg, J.N.; Oyler, G.A.; Wilkinson, L.; Betenbaugh, M.J. A green light for engineered algae: Redirecting metabolism to fuel a biotechnology revolution. Curr. Opin. Biotechnol. 2008, 19, 430-436. [CrossRef] [PubMed] 
5. Costa, J.A.V.; de Morais, M.G. 16 microalgae for food production. In Fermentation Processes Engineering in the Food Industry; CRC Press, Taylor \& Francis Group: Boca Raton, FL, USA, 2013; p. 405.

6. Fu, W.Q.; Wichuk, K.; Brynjolfsson, S. Developing diatoms for value-added products: Challenges and opportunities. New Biotechnol. 2015, 32, 547-551. [CrossRef] [PubMed]

7. Wichuk, K.; Brynjolfsson, S.; Fu, W.Q. Biotechnological production of value-added carotenoids from microalgae. Bioengineered 2014, 5, 204-208. [CrossRef] [PubMed]

8. Salehi-Ashtiani, K.; Koussa, J.; Dohai, B.S.; Chaiboonchoe, A.; Cai, H.; Dougherty, K.A.; Nelson, D.R.; Jijakli, K.; Khraiwesh, B. Toward applications of genomics and metabolic modeling to improve algal biomass productivity. In Biomass and Biofuels from Microalgae; Springer: Basel, Switzerland, 2015; pp. 173-189.

9. Gov, E.; Arga, K.Y. Systems biology solutions to challenges in marine biotechnology. Front. Mar. Sci. 2014, 1, 14. [CrossRef]

10. Xu, C.; Liu, L.; Zhang, Z.; Jin, D.; Qiu, J.; Chen, M. Genome-scale metabolic model in guiding metabolic engineering of microbial improvement. Appl. Microbiol. Biotechnol. 2013, 97, 519-539. [CrossRef] [PubMed]

11. Sarkar, D.; Shimizu, K. An overview on biofuel and biochemical production by photosynthetic microorganisms with understanding of the metabolism and by metabolic engineering together with efficient cultivation and downstream processing. Bioresour. Bioprocess. 2015, 2, 17. [CrossRef]

12. Mimouni, V.; Ulmann, L.; Pasquet, V.; Mathieu, M.; Picot, L.; Bougaran, G.; Cadoret, J.-P.; Morant-Manceau, A.; Schoefs, B. The potential of microalgae for the production of bioactive molecules of pharmaceutical interest. Curr. Pharm. Biotechnol. 2012, 13, 2733-2750. [CrossRef] [PubMed]

13. Kodym, A.; Afza, R. Physical and chemical mutagenesis. In Plant Functional Genomics; Humana Press, Inc.: Totowa, NJ, USA, 2003; pp. 189-203.

14. Pasquet, V.; Cherouvrier, J.R.; Farhat, F.; Thiery, V.; Piot, J.M.; Berard, J.B.; Kaas, R.; Serive, B.; Patrice, T.; Cadoret, J.P.; et al. Study on the microalgal pigments extraction process: Performance of microwave assisted extraction. Process. Biochem. 2011, 46, 59-67. [CrossRef]

15. Ikehata, H.; Ono, T. The mechanisms of UV mutagenesis. J. Radiat. Res. 2011, 52, 115-125. [CrossRef] [PubMed]

16. Depauw, F.A.; Rogato, A.; Ribera d'Alcala, M.; Falciatore, A. Exploring the molecular basis of responses to light in marine diatoms. J. Exp. Bot. 2012, 63, 1575-1591. [CrossRef] [PubMed]

17. Klanchui, A.; Khannapho, C.; Phodee, A.; Cheevadhanarak, S.; Meechai, A. iAK692: A genome-scale metabolic model of Spirulina platensis c1. BMC Syst. Biol. 2012, 6, 71. [CrossRef] [PubMed]

18. Liu, S.; Zhao, Y.; Liu, L.; Ao, X.; Ma, L.; Wu, M.; Ma, F. Improving cell growth and lipid accumulation in green microalgae Chlorella sp. Via UV irradiation. Appl. Biochem. Biotechnol. 2015, 175, 3507-3518. [CrossRef] [PubMed]

19. Abdrabu, R.; Sharma, S.K.; Khraiwesh, B.; Jijakli, K.; Nelson, D.R.; Alzahmi, A.; Koussa, J.; Sultana, M.; Khapli, S.; Jagannathan, R.; et al. Single-cell characterization of microalgal lipid contents with confocal raman microscopy. In Essentials of Single-Cell Analysis; Springer: Berlin, Germany, 2016; pp. 363-382.

20. Sharma, S.K.; Nelson, D.R.; Abdrabu, R.; Khraiwesh, B.; Jijakli, K.; Arnoux, M.; O'Connor, M.J.; Bahmani, T.; Cai, H.; Khapli, S.; et al. An integrative raman microscopy-based workflow for rapid in situ analysis of microalgal lipid bodies. Biotechnol. Biofuels 2015, 8, 164. [CrossRef] [PubMed]

21. Choi, J.-I.; Yoon, M.; Joe, M.; Park, H.; Lee, S.G.; Han, S.J.; Lee, P.C. Development of microalga Scenedesmus dimorphus mutant with higher lipid content by radiation breeding. Bioprocess Biosyst. Eng. 2014, 37, 2437-2444. [CrossRef] [PubMed]

22. Harper, M.; Lee, C.J. Genome-wide analysis of mutagenesis bias and context sensitivity of N-methyl-N'-nitro-N-nitrosoguanidine (NTG). Mutat. Res./Fundam. Mol. Mech. Mutagen. 2012, 731, 64-67. [CrossRef] [PubMed]

23. Kamath, B.S.; Vidhyavathi, R.; Sarada, R.; Ravishankar, G. Enhancement of carotenoids by mutation and stress induced carotenogenic genes in Haematococcus pluvialis mutants. Bioresour. Technol. 2008, 99, 8667-8673. [CrossRef] [PubMed]

24. Lee, B.; Choi, G.-G.; Choi, Y.-E.; Sung, M.; Park, M.S.; Yang, J.-W. Enhancement of lipid productivity by ethyl methane sulfonate-mediated random mutagenesis and proteomic analysis in Chlamydomonas reinhardtii. Korean J. Chem. Eng. 2014, 31, 1036-1042. [CrossRef] 
25. Applebee, M.K.; Joyce, A.R.; Conrad, T.M.; Pettigrew, D.W.; Palsson, B.O. Functional and metabolic effects of adaptive glycerol kinase (Glpk) mutants in Escherichia coli. J. Biol. Chem. 2011, 286, 23150-23159. [CrossRef] [PubMed]

26. Dragosits, M.; Mattanovich, D. Adaptive laboratory evolution-Principles and applications for biotechnology. Microb. Cell Fact. 2013, 12, 64. [CrossRef] [PubMed]

27. Lee, D.H.; Feist, A.M.; Barrett, C.L.; Palsson, B.O. Cumulative number of cell divisions as a meaningful timescale for adaptive laboratory evolution of Escherichia coli. PLoS ONE 2011, 6, e26172. [CrossRef] [PubMed]

28. Fu, W.; Guethmundsson, O.; Paglia, G.; Herjolfsson, G.; Andresson, O.S.; Palsson, B.O.; Brynjolfsson, S. Enhancement of carotenoid biosynthesis in the green microalga Dunaliella salina with light-emitting diodes and adaptive laboratory evolution. Appl. Microbiol. Biotechnol. 2013, 97, 2395-2403. [CrossRef] [PubMed]

29. Yi, Z.; Xu, M.; Magnusdottir, M.; Zhang, Y.; Brynjolfsson, S.; Fu, W. Photo-oxidative stress-driven mutagenesis and adaptive evolution on the marine diatom Phaeodactylum tricornutum for enhanced carotenoid accumulation. Mar. Drugs 2015, 13, 6138-6151. [CrossRef] [PubMed]

30. Tillich, U.M.; Wolter, N.; Franke, P.; Duhring, U.; Frohme, M. Screening and genetic characterization of thermo-tolerant Synechocystis sp. PCC6803 strains created by adaptive evolution. BMC Biotechnol. 2014, 14, 66. [CrossRef] [PubMed]

31. Uchiyama, J.; Kanesaki, Y.; Iwata, N.; Asakura, R.; Funamizu, K.; Tasaki, R.; Agatsuma, M.; Tahara, H.; Matsuhashi, A.; Yoshikawa, H.; et al. Genomic analysis of parallel-evolved cyanobacterium Synechocystis sp. PCC6803 under acid stress. Photosynth. Res. 2015, 125, 243-254. [CrossRef] [PubMed]

32. Wang, Y.; Shi, M.; Niu, X.; Zhang, X.; Gao, L.; Chen, L.; Wang, J.; Zhang, W. Metabolomic basis of laboratory evolution of butanol tolerance in photosynthetic Synechocystis sp. PCC6803. Microb. Cell Fact. 2014, 13, 151. [CrossRef] [PubMed]

33. Yu, S.; Zhao, Q.; Miao, X.; Shi, J. Enhancement of lipid production in low-starch mutants Chlamydomonas reinhardtii. by adaptive laboratory evolution. Bioresour. Technol. 2013, 147, 499-507. [CrossRef] [PubMed]

34. Velmurugan, N.; Sung, M.; Yim, S.S.; Park, M.S.; Yang, J.W.; Jeong, K.J. Systematically programmed adaptive evolution reveals potential role of carbon and nitrogen pathways during lipid accumulation in Chlamydomonas reinhardtii. Biotechnol. Biofuels 2014, 7, 117. [CrossRef] [PubMed]

35. Flowers, J.M.; Hazzouri, K.M.; Pham, G.M.; Rosas, U.; Bahmani, T.; Khraiwesh, B.; Nelson, D.R.; Jijakli, K.; Abdrabu, R.; Harris, E.H.; et al. Whole-genome resequencing reveals extensive natural variation in the model green alga Chlamydomonas reinhardtii. Plant Cell 2015, 27, 2353-2369. [CrossRef] [PubMed]

36. Li, D.; Wang, L.; Zhao, Q.; Wei, W.; Sun, Y. Improving high carbon dioxide tolerance and carbon dioxide fixation capability of Chlorella sp. By adaptive laboratory evolution. Bioresour. Technol. 2015, 185, 269-275. [CrossRef] [PubMed]

37. Bowler, C.; Allen, A.E.; Badger, J.H.; Grimwood, J.; Jabbari, K.; Kuo, A.; Maheswari, U.; Martens, C.; Maumus, F.; Otillar, R.P.; et al. The phaeodactylum genome reveals the evolutionary history of diatom genomes. Nature 2008, 456, 239-244. [CrossRef] [PubMed]

38. Coesel, S.; Obornik, M.; Varela, J.; Falciatore, A.; Bowler, C. Evolutionary origins and functions of the carotenoid biosynthetic pathway in marine diatoms. PLoS ONE 2008, 3, e2896. [CrossRef] [PubMed]

39. Schellenberger Costa, B.; Jungandreas, A.; Jakob, T.; Weisheit, W.; Mittag, M.; Wilhelm, C. Blue light is essential for high light acclimation and photoprotection in the diatom Phaeodactylum tricornutum. J. Exp. Bot. 2013, 64, 483-493. [CrossRef] [PubMed]

40. Lepetit, B.; Sturm, S.; Rogato, A.; Gruber, A.; Sachse, M.; Falciatore, A.; Kroth, P.G.; Lavaud, J. High light acclimation in the secondary plastids containing diatom Phaeodactylum tricornutum is triggered by the redox state of the plastoquinone pool. Plant Physiol. 2013, 161, 853-865. [CrossRef] [PubMed]

41. Lohbeck, K.T.; Riebesell, U.; Reusch, T.B.H. Adaptive evolution of a key phytoplankton species to ocean acidification (vol 5, pg 346, 2012). Nat. Geosci. 2012, 5, 917. [CrossRef]

42. Hempel, F.; Maier, U.G. An engineered diatom acting like a plasma cell secreting human IGG antibodies with high efficiency. Microb. Cell Fact. 2012, 11, 126. [CrossRef] [PubMed]

43. Wang, C.; Kim, J.H.; Kim, S.W. Synthetic biology and metabolic engineering for marine carotenoids: New opportunities and future prospects. Mar. Drugs 2014, 12, 4810-4832. [CrossRef] [PubMed] 
44. Jijakli, K.; Abdrabu, R.; Khraiwesh, B.; Nelson, D.R.; Koussa, J.; Salehi-Ashtiani, K. Molecular genetic techniques for algal bioengineering. In Biomass and Biofuels from Microalgae; Springer: Basel, Switzerland, 2015; pp. 155-171.

45. Leon, R.; Couso, I.; Fernandez, E. Metabolic engineering of ketocarotenoids biosynthesis in the unicelullar microalga Chlamydomonas reinhardtii. J. Biotechnol. 2007, 130, 143-152. [CrossRef] [PubMed]

46. Cordero, B.F.; Obraztsova, I.; Couso, I.; Leon, R.; Vargas, M.A.; Rodriguez, H. Enhancement of lutein production in Chlorella sorokiniana (chorophyta) by improvement of culture conditions and random mutagenesis. Mar. Drugs 2011, 9, 1607-1624. [CrossRef] [PubMed]

47. Couso, I.; Cordero, B.F.; Vargas, M.A.; Rodriguez, H. Efficient heterologous transformation of Chlamydomonas reinhardtii npq2 mutant with the zeaxanthin epoxidase gene isolated and characterized from C hlorella zofingiensis. Mar. Drugs 2012, 10, 1955-1976. [CrossRef] [PubMed]

48. Apt, K.E.; Kroth-Pancic, P.G.; Grossman, A.R. Stable nuclear transformation of the diatom Phaeodactylum tricornutum. Mol. Gen. Genet. 1996, 252, 572-579. [PubMed]

49. Miyahara, M.; Aoi, M.; Inoue-Kashino, N.; Kashino, Y.; Ifuku, K. Highly efficient transformation of the diatom Phaeodactylum tricornutum by multi-pulse electroporation. Biosci. Biotechnol. Biochem. 2013, 77, 874-876. [CrossRef] [PubMed]

50. Hamilton, M.L.; Haslam, R.P.; Napier, J.A.; Sayanova, O. Metabolic engineering of Phaeodactylum tricornutum for the enhanced accumulation of omega-3 long chain polyunsaturated fatty acids. Metab. Eng. 2014, 22, 3-9. [CrossRef] [PubMed]

51. Kumar, S.V.; Misquitta, R.W.; Reddy, V.S.; Rao, B.J.; Rajam, M.V. Genetic transformation of the green alga-Chlamydomonas reinhardtii by agrobacterium tumefaciens. Plant Sci. 2004, 166, 731-738. [CrossRef]

52. Rathod, J.; Prakash, G.; Pandit, R.; Lali, A. Agrobacterium-mediated transformation of promising oil-bearing marine algae Parachlorella kessleri. Photosynth. Res. 2013, 118, 141-146. [CrossRef] [PubMed]

53. Cheng, R.B.; Ma, R.J.; Li, K.; Rong, H.; Lin, X.Z.; Wang, Z.K.; Yang, S.J.; Ma, Y. Agrobacterium tumefaciens mediated transformation of marine microalgae schizochytrium. Microbiol. Res. 2012, 167, 179-186. [CrossRef] [PubMed]

54. Hlavova, M.; Turoczy, Z.; Bisova, K. Improving microalgae for biotechnology-from genetics to synthetic biology. Biotechnol. Adv. 2015, 33, 1194-1203. [CrossRef] [PubMed]

55. Jiang, W.; Brueggeman, A.J.; Horken, K.M.; Plucinak, T.M.; Weeks, D.P. Successful transient expression of Cas9 and single guide RNA genes in Chlamydomonas reinhardtii. Eukaryot. Cell 2014, 13, 1465-1469. [CrossRef] [PubMed]

56. Shin, S.-E.; Lim, J.-M.; Koh, H.G.; Kim, E.K.; Kang, N.K.; Jeon, S.; Kwon, S.; Shin, W.-S.; Lee, B.; Hwangbo, K.; et al. CRISPR/Cas9-induced knockout and knock-in mutations in Chlamydomonas reinhardtii. Sci. Rep. 2016, 6, 27810. [CrossRef] [PubMed]

57. Nymark, M.; Sharma, A.K.; Sparstad, T.; Bones, A.M.; Winge, P. A crispr/cas9 system adapted for gene editing in marine algae. Sci. Rep. 2016, 6, 24951. [CrossRef] [PubMed]

58. Khraiwesh, B.; Jijakli, K.; Swift, J.; Chaiboonchoe, A.; Abdrabu, R.; Chao, P.-W.; Yen, L.; Salehi-Ashtiani, K. Prospective applications of synthetic biology for algal bioproduct optimization. In Biomass and Biofuels from Microalgae; Springer International Publishing: Basel, Switzerland, 2015; Volume 2, pp. 137-154.

59. Karas, B.J.; Molparia, B.; Jablanovic, J.; Hermann, W.J.; Lin, Y.C.; Dupont, C.L.; Tagwerker, C.; Yonemoto, I.T.; Noskov, V.N.; Chuang, R.Y.; et al. Assembly of eukaryotic algal chromosomes in yeast. J. Biol. Eng. 2013, 7, 30. [CrossRef] [PubMed]

60. Chaiboonchoe, A.; Ghamsari, L.; Dohai, B.; Ng, P.; Khraiwesh, B.; Jaiswal, A.; Jijakli, K.; Koussa, J.; Nelson, D.R.; Cai, H.; et al. Systems level analysis of the Chlamydomonas reinhardtii metabolic network reveals variability in evolutionary co-conservation. Mol. BioSyst. 2016, 12, 2394-2407. [CrossRef] [PubMed]

61. Dai, Z.; Nielsen, J. Advancing metabolic engineering through systems biology of industrial microorganisms. Curr. Opin. Biotechnol. 2015, 36, 8-15. [CrossRef] [PubMed]

62. Guarnieri, M.T.; Pienkos, P.T. Algal omics: Unlocking bioproduct diversity in algae cell factories. Photosynth. Res. 2015, 123, 255-263. [CrossRef] [PubMed]

63. Schellenberger, J.; Que, R.; Fleming, R.M.; Thiele, I.; Orth, J.D.; Feist, A.M.; Zielinski, D.C.; Bordbar, A.; Lewis, N.E.; Rahmanian, S. Quantitative prediction of cellular metabolism with constraint-based models: The cobra toolbox v2. 0. Nat. Protoc. 2011, 6, 1290-1307. [CrossRef] [PubMed] 
64. Koussa, J.; Chaiboonchoe, A.; Salehi-Ashtiani, K. Computational approaches for microalgal biofuel optimization: A review. BioMed Res. Int. 2014, 649453. [CrossRef] [PubMed]

65. Karp, P.D.; Latendresse, M.; Paley, S.M.; Krummenacker, M.; Ong, Q.D.; Billington, R.; Kothari, A.; Weaver, D.; Lee, T.; Subhraveti, P. Pathway tools version 19.0 update: Software for pathway/genome informatics and systems biology. Brief. Bioinform. 2015. [CrossRef] [PubMed]

66. Kim, J.; Reed, J.L. Optorf: Optimal metabolic and regulatory perturbations for metabolic engineering of microbial strains. BMC Syst. Biol. 2010, 4, 53. [CrossRef] [PubMed]

67. Wagner, A.; Zarecki, R.; Reshef, L.; Gochev, C.; Sorek, R.; Gophna, U.; Ruppin, E. Computational evaluation of cellular metabolic costs successfully predicts genes whose expression is deleterious. Proc. Natl. Acad. Sci. USA 2013, 110, 19166-19171. [CrossRef] [PubMed]

68. Burgard, A.P.; Pharkya, P.; Maranas, C.D. Optknock: A bilevel programming framework for identifying gene knockout strategies for microbial strain optimization. Biotechnol. Bioeng. 2003, 84, 647-657. [CrossRef] [PubMed]

69. Imam, S.; Schäuble, S.; Valenzuela, J.; López García de Lomana, A.; Carter, W.; Price, N.D.; Baliga, N.S. A refined genome-scale reconstruction of chlamydomonas metabolism provides a platform for systems-level analyses. Plant J. 2015, 1239-1256. [CrossRef] [PubMed]

70. Chaiboonchoe, A.; Dohai, B.S.; Cai, H.; Nelson, D.R.; Jijakli, K.; Salehi-Ashtiani, K. Microalgal metabolic network model refinement through high-throughput functional metabolic profiling. Front. Bioeng. Biotechnol. 2014, 2, 68. [CrossRef] [PubMed]

71. Krumholz, E.W.; Yang, H.; Weisenhorn, P.; Henry, C.S.; Libourel, I.G. Genome-wide metabolic network reconstruction of the Picoalga ostreococcus. J. Exp. Bot. 2012, 63, 2353-2362. [CrossRef] [PubMed]

72. Hunt, K.A.; Folsom, J.P.; Taffs, R.L.; Carlson, R.P. Complete enumeration of elementary flux modes through scalable, demand-based subnetwork definition. Bioinformatics 2014, 30, 1569-1578. [CrossRef] [PubMed]

73. Levering, J.; Broddrick, J.; Dupont, C.L.; Peers, G.; Beeri, K.; Mayers, J.; Gallina, A.A.; Allen, A.E.; Palsson, B.O.; Zengler, K. Genome-scale model reveals metabolic basis of biomass partitioning in a model diatom. PLoS ONE 2016, 11, e0155038. [CrossRef] [PubMed]

74. Singh, D.; Carlson, R.; Fell, D.; Poolman, M. Modelling metabolism of the diatom Phaeodactylum tricornutum. Biochem. Soc. Trans. 2015, 43, 1182-1186. [CrossRef] [PubMed]

75. Gao, C.; Wang, Y.; Shen, Y.; Yan, D.; He, X.; Dai, J.; Wu, Q. Oil accumulation mechanisms of the oleaginous microalga Chlorella protothecoides revealed through its genome, transcriptomes, and proteomes. BMC Genom. 2014, 15, 582. [CrossRef] [PubMed]

76. Wu, C.; Xiong, W.; Dai, J.; Wu, Q. Genome-based metabolic mapping and 13c flux analysis reveal systematic properties of an oleaginous microalga Chlorella protothecoides. Plant Physiol. 2015, 167, 586-599. [CrossRef] [PubMed]

77. Juneja, A.; Chaplen, F.W.; Murthy, G.S. Genome scale metabolic reconstruction of Chlorella variabilis for exploring its metabolic potential for biofuels. Bioresour. Technol. 2016, 213, 103-110. [CrossRef] [PubMed]

78. Zuñiga, C.; Li, C.-T.; Huelsman, T.; Levering, J.; Zielinski, D.C.; McConnell, B.O.; Long, C.P.; Knoshaug, E.P.; Guarnieri, M.T.; Antoniewicz, M.R. Genome-scale metabolic model for the green alga Chlorella vulgaris utex 395 accurately predicts phenotypes under autotrophic, heterotrophic, and mixotrophic growth conditions. Plant Physiol. 2016, 589-602. [CrossRef] [PubMed]

79. Bochner, B.R.; Gadzinski, P.; Panomitros, E. Phenotype microarrays for high-throughput phenotypic testing and assay of gene function. Genome Res. 2001, 11, 1246-1255. [CrossRef] [PubMed]

80. Knoop, H.; Gründel, M.; Zilliges, Y.; Lehmann, R.; Hoffmann, S.; Lockau, W.; Steuer, R. Flux balance analysis of cyanobacterial metabolism: The metabolic network of Synechocystis sp. PCC6803. PLoS Comput. Biol. 2013, 9, e1003081. [CrossRef] [PubMed]

81. Nakajima, T.; Kajihata, S.; Yoshikawa, K.; Matsuda, F.; Furusawa, C.; Hirasawa, T.; Shimizu, H. Integrated metabolic flux and omics analysis of Synechocystis sp. PCC6803 under mixotrophic and photoheterotrophic conditions. Plant Cell Physiol. 2014, 55, 1605-1612. [CrossRef] [PubMed]

82. Triana, J.; Montagud, A.; Siurana, M.; Fuente, D.; Urchueguía, A.; Gamermann, D.; Torres, J.; Tena, J.; de Córdoba, P.F.; Urchueguía, J.F. Generation and evaluation of a genome-scale metabolic network model of Synechococcus elongatus PCC7942. Metabolites 2014, 4, 680-698. [CrossRef] [PubMed] 
83. Montagud, A.; Navarro, E.; de Córdoba, P.F.; Urchueguía, J.F.; Patil, K.R. Reconstruction and analysis of genome-scale metabolic model of a photosynthetic bacterium. BMC Syst. Biol. 2010, 4, 156. [CrossRef] [PubMed]

84. Nogales, J.; Gudmundsson, S.; Knight, E.M.; Palsson, B.O.; Thiele, I. Detailing the optimality of photosynthesis in cyanobacteria through systems biology analysis. Proc. Natl. Acad. Sci. USA 2012, 109, 2678-2683. [CrossRef] [PubMed]

85. Vitkin, E.; Shlomi, T. Mirage: A functional genomics-based approach for metabolic network model reconstruction and its application to cyanobacteria networks. Genome Biol. 2012, 13, R111. [CrossRef] [PubMed]

86. Hernández-Prieto, M.A.; Semeniuk, T.A.; Futschik, M.E. Toward a systems-level understanding of gene regulatory, protein interaction, and metabolic networks in cyanobacteria. Front. Genet. 2014, 5, 191. [CrossRef] [PubMed]

87. Lau, N.-S.; Matsui, M.; Abdullah, A.A.-A. Cyanobacteria: Photoautotrophic microbial factories for the sustainable synthesis of industrial products. BioMed Res. Int. 2015, 754934. [CrossRef] [PubMed]

88. Johnson, T.J.; Gibbons, J.L.; Gu, L.; Zhou, R.; Gibbons, W.R. Molecular genetic improvements of cyanobacteria to enhance the industrial potential of the microbe: A review. Biotechnol. Prog. 2016. [CrossRef] [PubMed]

89. Ye, C.; Qiao, W.; Yu, X.; Ji, X.; Huang, H.; Collier, J.; Liu, L. Reconstruction and analysis of the genome-scale metabolic model of schizochytrium limacinum sr21 for docosahexaenoic acid production. BMC Genom. 2015, 16, 799. [CrossRef] [PubMed]

90. Hao, T.; Han, B.; Ma, H.; Fu, J.; Wang, H.; Wang, Z.; Tang, B.; Chen, T.; Zhao, X. In silico metabolic engineering of Bacillus subtilis for improved production of riboflavin, Egl-237,(R,R)-2, 3-butanediol and isobutanol. Mol. BioSyst. 2013, 9, 2034-2044. [CrossRef] [PubMed]

91. Rensing, S.A.; Lang, D.; Zimmer, A.D.; Terry, A.; Salamov, A.; Shapiro, H.; Nishiyama, T.; Perroud, P.-F.; Lindquist, E.A.; Kamisugi, Y. The physcomitrella genome reveals evolutionary insights into the conquest of land by plants. Science 2008, 319, 64-69. [CrossRef] [PubMed]

92. Frank, W.; Decker, E.; Reski, R. Molecular tools to study Physcomitrella patens. Plant Biol. 2005, 7, $220-227$. [CrossRef] [PubMed]

93. Reski, R. Development, genetics and molecular biology of mosses. Bot. Acta 1998, 111, 1-15. [CrossRef]

94. Trosset, J.-Y.; Carbonell, P. Synthetic biology for pharmaceutical drug discovery. Drug Des. Dev. Ther. 2015, 9, 6285-6302. [CrossRef] [PubMed]

95. Rorrer, G.L. Bioprocess engineering of phototrophic marine organisms. In Springer Handbook of Marine Biotechnology; Kim, S.-K., Ed.; Springer: Berlin/Heidelberg, Germany, 2015; pp. 257-294.

96. Holdt, S.L.; Kraan, S. Bioactive compounds in seaweed: Functional food applications and legislation. J. Appl. Phycol. 2011, 23, 543-597. [CrossRef]

97. Rorrer, G.L.; Mullikin, R.; Huang, B.; Gerwick, W.H.; Maliakal, S.; Cheney, D.P. Production of bioactive metabolites by cell and tissue cultures of marine macroalgae in bioreactor systems. In Plant Cell and Tissue Culture for the Production of Food Ingredients; Fu, T.-J., Singh, G., Curtis, W.R., Eds.; Springer: Boston, MA, USA, 1999; pp. 165-184.

98. Armin, H. Algae biotechnology-green cell-factories on the rise. Curr. Biotechnol. 2015, 4, 389-415.

99. Lin, H.; Qin, S. Tipping points in seaweed genetic engineering: Scaling up opportunities in the next decade. Mar. Drugs 2014, 12, 3025-3045. [CrossRef] [PubMed]

100. Food and Agriculture Organization of the United Nations. Available online: http://www.fao.org/home/en/ (accessed on 30 November 2016).

101. Khraiwesh, B.; Qudeimat, E.; Thimma, M.; Chaiboonchoe, A.; Jijakli, K.; Alzahmi, A.; Arnoux, M.; Salehi-Ashtiani, K. Genome-wide expression analysis offers new insights into the origin and evolution of Physcomitrella patens stress response. Sci. Rep. 2015, 5, 17434. [CrossRef] [PubMed]

102. Reski, R.; Parsons, J.; Decker, E.L. Moss-made pharmaceuticals: From bench to bedside. Plant Biotechnol. J. 2015, 13, 1191-1198. [CrossRef] [PubMed]

103. Huether, C.M.; Lienhart, O.; Baur, A.; Stemmer, C.; Gorr, G.; Reski, R.; Decker, E.L. Glyco-engineering of moss lacking plant-specific sugar residues. Plant Biol. 2005, 7, 292-299. [CrossRef] [PubMed]

104. Parsons, J.; Altmann, F.; Graf, M.; Stadlmann, J.; Reski, R.; Decker, E.L. A gene responsible for prolyl-hydroxylation of moss-produced recombinant human erythropoietin. Sci. Rep. 2013, 3, 3019. [CrossRef] [PubMed] 
105. Baur, A.; Reski, R.; Gorr, G. Enhanced recovery of a secreted recombinant human growth factor using stabilizing additives and by co-expression of human serum albumin in the moss Physcomitrella patens. Plant Biotechnol. J. 2005, 3, 331-340. [CrossRef] [PubMed]

106. Goel, H.L.; Mercurio, A.M. Vegf targets the tumour cell. Nat. Rev. Cancer 2013, 13, 871-882. [CrossRef] [PubMed]

107. Niederkrüger, H.; Dabrowska-Schlepp, P.; Schaaf, A. Suspension culture of plant cells under phototrophic conditions. In Industrial Scale Suspension Culture of Living Cells; Wiley-VCH Verlag GmbH \& Co. KGaA: Weinheim, Germany, 2014; pp. 259-292.

108. Rosales-Mendoza, S.; Orellana-Escobedo, L.; Romero-Maldonado, A.; Decker, E.L.; Reski, R. The potential of Physcomitrella patens as a platform for the production of plant-based vaccines. Expert Rev. Vaccines 2014, 13, 203-212. [CrossRef] [PubMed]

109. Orellana-Escobedo, L.; Rosales-Mendoza, S.; Romero-Maldonado, A.; Parsons, J.; Decker, E.L.; Monreal-Escalante, E.; Moreno-Fierros, L.; Reski, R. An env-derived multi-epitope hiv chimeric protein produced in the moss Physcomitrella patens is immunogenic in mice. Plant Cell Rep. 2015, 34, 425-433. [CrossRef] [PubMed]

110. Schulte, J.; Reski, R. High throughput cryopreservation of 140000 Physcomitrella patens mutants. Plant Biol. 2004, 6, 119-127. [CrossRef] [PubMed]

111. Guiry, M.; Guiry, G. World-Wide Electronic Publication. National University of Ireland, Galway. Available online: http:/ /www.algaebase.org (accessed on 31 October 2016).

112. Suzuki, S.; Shirato, S.; Hirakawa, Y.; Ishida, K.-I. Nucleomorph genome sequences of two chlorarachniophytes, Amorphochlora amoebiformis and Lotharella vacuolata. Genome Biol. Evol. 2015, 7, 1533-1545. [CrossRef] [PubMed]

113. Curtis, B.A.; Tanifuji, G.; Burki, F.; Gruber, A.; Irimia, M.; Maruyama, S.; Arias, M.C.; Ball, S.G.; Gile, G.H.; Hirakawa, Y. Algal genomes reveal evolutionary mosaicism and the fate of nucleomorphs. Nature 2012, 492, 59-65. [CrossRef] [PubMed]

114. Blanc, G.; Gallot-Lavallée, L.; Maumus, F. Provirophages in the bigelowiella genome bear testimony to past encounters with giant viruses. Proc. Natl. Acad. Sci. USA 2015, 112, E5318-E5326. [CrossRef] [PubMed]

115. Rasala, B.A.; Mayfield, S.P. Photosynthetic biomanufacturing in green algae; production of recombinant proteins for industrial, nutritional, and medical uses. Photosynth. Res. 2015, 123, 227-239. [CrossRef] [PubMed]

116. Yamada, T.; Chuchird, N.; Kawasaki, T.; Nishida, K.; Hiramatsu, S. Chlorella viruses as a source of novel enzymes. J. Biosci. Bioeng. 1999, 88, 353-361. [CrossRef]

117. Hawkins, R.L.; Nakamura, M. Expression of human growth hormone by the eukaryotic alga, chlorella. Curr. Microbiol. 1999, 38, 335-341. [CrossRef] [PubMed]

118. Misra, N.; Patra, M.C.; Panda, P.K.; Sukla, L.B.; Mishra, B.K. Homology modeling and docking studies of fabh ( $\beta$-ketoacyl-ACP synthase III) enzyme involved in type II fatty acid biosynthesis of Chlorella variabilis: A potential algal feedstock for biofuel production. J. Biomol. Struct. Dyn. 2013, 31, 241-257. [CrossRef] [PubMed]

119. Hu, L.; Li, H.; Qin, R.; Xu, R.; Li, J.; Li, L.; Wei, P.; Yang, J. Plant phosphomannose isomerase as a selectable marker for rice transformation. Sci. Rep. 2016, 6, 25921. [CrossRef] [PubMed]

120. Vogt, A.; Guo, Y.; Tsunoda, S.; Kateriya, S.; Elstner, M.; Hegemann, P. Conversion of a light-driven proton pump into a light-gated ion channel. Sci. Rep. 2015, 5, 16450. [CrossRef] [PubMed]

121. Botebol, H.; Lesuisse, E.; Šuták, R.; Six, C.; Lozano, J.-C.; Schatt, P.; Vergé, V.; Kirilovsky, A.; Morrissey, J.; Léger, T. Central role for ferritin in the day/night regulation of iron homeostasis in marine phytoplankton. Proc. Natl. Acad. Sci. USA 2015, 112, 14652-14657. [CrossRef] [PubMed]

122. Blatt, A.; Bauch, M.E.; Pörschke, Y.; Lohr, M. A lycopene $\beta$-cyclase/lycopene $\varepsilon$-cyclase/light-harvesting complex-fusion protein from the green alga Ostreococcus lucimarinus can be modified to produce $\alpha$-carotene and $\beta$-carotene at different ratios. Plant J. 2015, 82, 582-595. [CrossRef] [PubMed]

123. Shi, H.; Chen, H.; Gu, Z.; Zhang, H.; Chen, W.; Chen, Y.Q. Application of a delta- 6 desaturase with $\alpha$-linolenic acid preference on eicosapentaenoic acid production in Mortierella alpina. Microb. Cell Fact. 2016, 15, 117. [CrossRef] [PubMed]

124. von Der Heyde, E.L.; Klein, B.; Abram, L.; Hallmann, A. The inducible nita promoter provides a powerful molecular switch for transgene expression in Volvox carteri. BMC Biotechnol. 2015, 15, 5. [CrossRef] [PubMed] 
125. Adarme-Vega, T.C.; Lim, D.K.Y.; Timmins, M.; Vernen, F.; Li, Y.; Schenk, P.M. Microalgal biofactories: A promising approach towards sustainable omega-3 fatty acid production. Microb. Cell Fact. 2012, 11, 96. [CrossRef] [PubMed]

126. Chlamydomonas Resource Center. Methods. Available online: http://www.chlamycollection.org/methods/ (accessed on 30 November 2016).

127. Quinn, P.; Bowers, R.M.; Zhang, X.; Wahlund, T.M.; Fanelli, M.A.; Olszova, D.; Read, B.A. cDna microarrays as a tool for identification of biomineralization proteins in the Coccolithophorid Emiliania huxleyi (haptophyta). Appl. Environ. Microbiol. 2006, 72, 5512-5526. [CrossRef] [PubMed]

128. Endo, H.; Yoshida, M.; Uji, T.; Saga, N.; Inoue, K.; Nagasawa, H. Stable nuclear transformation system for the Coccolithophorid alga Pleurochrysis carterae. Sci. Rep. 2016, 6, 22252. [CrossRef] [PubMed]

129. Sineshchekov, O.A.; Govorunova, E.G.; Jung, K.-H.; Zauner, S.; Maier, U.-G.; Spudich, J.L. Rhodopsin-mediated photoreception in cryptophyte flagellates. Biophys. J. 2005, 89, 4310-4319. [CrossRef] [PubMed]

130. Vieler, A.; Wu, G.; Tsai, C.-H.; Bullard, B.; Cornish, A.J.; Harvey, C.; Reca, I.-B.; Thornburg, C.; Achawanantakun, R.; Buehl, C.J. Genome, functional gene annotation, and nuclear transformation of the heterokont oleaginous alga Nannochloropsis oceanica CCMP1779. PLoS Genet. 2012, 8, e1003064. [CrossRef] [PubMed]

131. Iwai, M.; Hori, K.; Sasaki-Sekimoto, Y.; Shimojima, M.; Ohta, H. Manipulation of oil synthesis in nannochloropsis strain nies-2145 with a phosphorus starvation-inducible promoter from Chlamydomonas reinhardtii. Front. Microbiol. 2015, 6, 912. [CrossRef] [PubMed]

132. Charrier, B.; Rolland, E.; Gupta, V.; Reddy, C. Production of genetically and developmentally modified seaweeds: Exploiting the potential of artificial selection techniques. Front. Plant Sci. 2015, 6, 127. [CrossRef] [PubMed]

133. Zhang, N.; Zhang, L.; Tao, Y.; Guo, L.; Sun, J.; Li, X.; Zhao, N.; Peng, J.; Li, X.; Zeng, L. Construction of a high density snp linkage map of kelp (Saccharina japonica) by sequencing taq I site associated DNA and mapping of a sex determining locus. BMC Genom. 2015, 16, 189. [CrossRef] [PubMed]

134. Trentacoste, E.M.; Shrestha, R.P.; Smith, S.R.; Glé, C.; Hartmann, A.C.; Hildebrand, M.; Gerwick, W.H. Metabolic engineering of lipid catabolism increases microalgal lipid accumulation without compromising growth. Proc. Natl. Acad. Sci. USA 2013, 110, 19748-19753. [CrossRef] [PubMed]

135. Moog, D.; Stork, S.; Zauner, S.; Maier, U.-G. In silico and in vivo investigations of proteins of a minimized eukaryotic cytoplasm. Genome Biol. Evol. 2011, 3, 375-382. [CrossRef] [PubMed]

136. Karas, B.J.; Diner, R.E.; Lefebvre, S.C.; McQuaid, J.; Phillips, A.P.; Noddings, C.M.; Brunson, J.K.; Valas, R.E.; Deerinck, T.J.; Jablanovic, J. Designer diatom episomes delivered by bacterial conjugation. Nat. Commun. 2015, 6, 6925. [CrossRef] [PubMed]

137. Sumiya, N.; Fujiwara, T.; Kobayashi, Y.; Misumi, O.; Miyagishima, S.-Y. Development of a heat-shock inducible gene expression system in the red alga Cyanidioschyzon merolae. PLoS ONE 2014, 9, e111261. [CrossRef] [PubMed]

138. Takusagawa, M.; Nakajima, Y.; Saito, T.; Misumi, O. Primitive red alga Cyanidioschyzon merolae accumulates storage glucan and triacylglycerol under nitrogen depletion. J. Gen. Appl. Microbiol. 2016, 62, 111-117. [CrossRef] [PubMed]

139. Rulong, L. Pyropia conchocelis: Potential as an algal source for carotenoid extraction. Am. J. BioSci. 2015, 3, 121. [CrossRef]

140. Takenaka, S.; Sugiyama, S.; Ebara, S.; Miyamoto, E.; Abe, K.; Tamura, Y.; Watanabe, F.; Tsuyama, S.; Nakano, Y. Feeding dried purple laver (nori) to vitamin b12-deficient rats significantly improves vitamin b12 status. $\mathrm{Br}$. J. Nutr. 2007, 85, 699. [CrossRef]

141. Cian, R.E.; Drago, S.R.; de Medina, F.S.; Martinez-Augustin, O. Proteins and carbohydrates from red seaweeds: Evidence for beneficial effects on gut function and microbiota. Mar. Drugs 2015, 13, 5358-5383. [CrossRef] [PubMed]

142. Choi, Y.H.; Kim, E.-Y.; Mikami, K.; Nam, T.J. Chemoprotective effects of a recombinant protein from pyropia yezoensis and synthetic peptide against acetaminophen-induced chang liver cell death. Int. J. Mol. Med. 2015, 36, 369-376. [CrossRef] [PubMed]

143. Barbosa, M.; Valentao, P.; Andrade, P.B. Biologically active oxylipins from enzymatic and nonenzymatic routes in macroalgae. Mar. Drugs 2016, 14, 23. [CrossRef] [PubMed] 
144. Thornton, D.C.; Chen, J. Exopolymer production as a function of cell permeability and death in a diatom (Thalassiosira weissflogii) and a cyanobacterium (Synechococcus elongatus). J. Phycol. 2016. [CrossRef] [PubMed]

145. Takaichi, S. Carotenoids in algae: Distributions, biosyntheses and functions. Mar. Drugs 2011, 9, 1101-1118. [CrossRef] [PubMed]

146. Chénard, C.; Wirth, J.F.; Suttle, C.A. Viruses infecting a freshwater filamentous cyanobacterium (Nostoc sp.) encode a functional crispr array and a proteobacterial DNA polymerase B. mBio 2016, 7, e00667-00616. [CrossRef] [PubMed]

147. Heidorn, T.; Camsund, D.; Huang, H.-H.; Lindberg, P.; Oliveira, P.; Stensjö, K.; Lindblad, P. Synthetic biology in cyanobacteria engineering and analyzing novel functions. Methods Enzymol. 2010, 497, 539-579.

148. Shishido, T.K.; Humisto, A.; Jokela, J.; Liu, L.; Wahlsten, M.; Tamrakar, A.; Fewer, D.P.; Permi, P.; Andreote, A.P.; Fiore, M.F.; et al. Antifungal compounds from cyanobacteria. Mar. Drugs 2015, 13, $2124-2140$. [CrossRef] [PubMed]

149. Chen, K.; Xu, X.; Gu, L.; Hildreth, M.; Zhou, R. Simultaneous gene inactivation and promoter reporting in cyanobacteria. Appl. Microbiol. Biotechnol. 2015, 99, 1779-1793. [CrossRef] [PubMed]

150. Gangl, D.; Zedler, J.A.Z.; Rajakumar, P.D.; Martinez, E.M.R.; Riseley, A.; Wlodarczyk, A.; Purton, S.; Sakuragi, Y.; Howe, C.J.; Jensen, P.E.; et al. Biotechnological exploitation of microalgae. J. Exp. Bot. 2015, 66, 6975-6990. [CrossRef] [PubMed]

151. Ledford, H. Gene-editing surges as us rethinks regulations. Nat. News 2016, 532, 158-159. [CrossRef] [PubMed]

152. U.S Food \& Drug Administration: Statement of Policy-Foods Derived from New Plant Varieties. Available online: http:/ / www.fda.gov / Food/GuidanceRegulation/GuidanceDocumentsRegulatoryInformation/ Biotechnology/ucm096095.htm (accessed on 30 November 2016).

153. Greenwell, H.C.; Laurens, L.M.L.; Shields, R.J.; Lovitt, R.W.; Flynn, K.J. Placing microalgae on the biofuels priority list: A review of the technological challenges. J. R. Soc. Interface 2010, 7, 703-726. [CrossRef] [PubMed]

(C) 2016 by the authors; licensee MDPI, Basel, Switzerland. This article is an open access article distributed under the terms and conditions of the Creative Commons Attribution (CC-BY) license (http://creativecommons.org/licenses/by/4.0/). 